\title{
HYDROSTATIC SYSTEM FOR OPERATIONS WITH HEAVY CARGO
}

\section{ГІДРОСТАТИЧНА СИСТЕМА ДЛЯ ОПЕРАЦЙ 3 НАДВАЖКИМИ ВАНТАЖАМИ}

\author{
Sandler A.K., assistant professor, Drozd E.V. assistant professor \\ Сандлер А.К., доцент, Дрозд О. В., доиент \\ Національний університет «Одеська морська академія», Украӥна \\ National University «Odessa Maritime Academy», Ukraine
}

\begin{abstract}
Special role in the transportation of heavy cargo is played by hydrostatic rigging systems designed for horizontal cargo operations on ships. This is due to a number of advantages of rigging cargo guides over traditional ones - they are low cost, easy to operate and easy to mount systems for loads of different weights.

At the same time, the use of existing hydrostatic rigging systems revealed their incomplete compliance with modern tasks for the safe operation of cargo operations. In order to find ways to improve the operational characteristics of freight rails, the schematic solutions of their lubrication systems are analyzed.

In the prevailing conditions, it was expedient to develop a new circuit design solution for lubrication of guides. It was supposed that constructive implementation should ensure:

- the possibility of using high-viscosity lubricants with the necessary and sufficient flow of these materials;

- minimized influence of climatic factors on cargo operations;

- independence from power supply;

- high level of liquid friction in the whole range of speeds and loads when moving a load;

- simplicity and reliability of circuit design solutions of known types.

For the solution of the problem, a diagram of the lubrication system of the guides is proposed.

The proposed circuit design differs in that the system involves the capacity for the lubrication cartridge, a power secondary cylinder, whose piston rod, under the influence of pressure, creating six primary cylinders having an actuator from the device for converting the translational motion into the rotary and toothed rails, compresses lubricant cartridge and provides lubricant in the lubrication pockets.

The use of the offered device will allow to carry out an adequate and economical mode of lubrication while moving along the guides of heavy duty loads.
\end{abstract}

Keywords: guide, load, lubricant. 


\section{Постановка проблеми в загальному вигляді та її зв'язок 3 важливими науковими та практичними задачами}

В сучасний час у світі сформувалася тверда тенденція росту обсягів перевезення надважких вантажів, що обумовлено необхідністю транспортування суден та нафтових платформ, технологічних модулів та обладнання для виробництв з нафтопереробки та скраплення природного газу. Вага особливо важких вантажів складає сотні й десятки тисяч тон, а їх габарити - десятки й сотні метрів. Як показує світова практика, для перевозок таких вантажів застосовуються спеціальні судна и плавучі засоби: вантажні судналіфти, транспортні плавучі доки, баржи та понтони, ліхтеровози тощо (рис. 1) $[1]$.

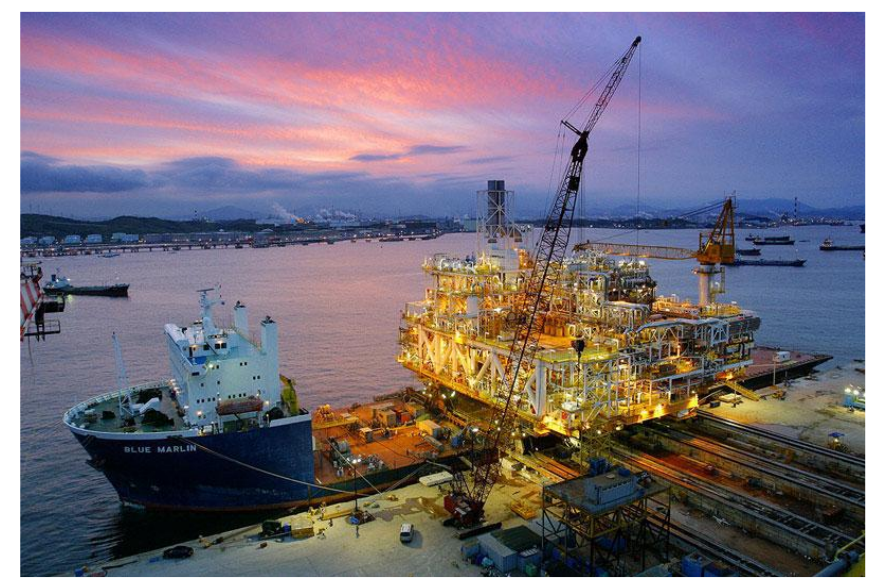

Рис. 1. Вивантаження надважкого вантажу по рейках на берег

Особливу роль при перевезенні надважких вантажів відіграють гідростатичні такелажні системи, призначені для горизонтальних вантажних операцій на суднах. Це обумовлено низкою переваг такелажних вантажних напрямних над традиційними - вони мають низьку вартість, прості у експлуатації та з них легко монтуються системи під вантажі різної ваги (рис. 2).

У той же час, застосування існуючих гідростатичних такелажних систем виявило їх неповну відповідність сучасним задачам безпечного здійснення вантажних операцій $[1,2,3]$. Для пошуку шляхів поліпшення експлуатаційних характеристик вантажних такелажних напрямних проаналізовані схемотехнічні рішення їх систем змащування $[3,4,5]$.

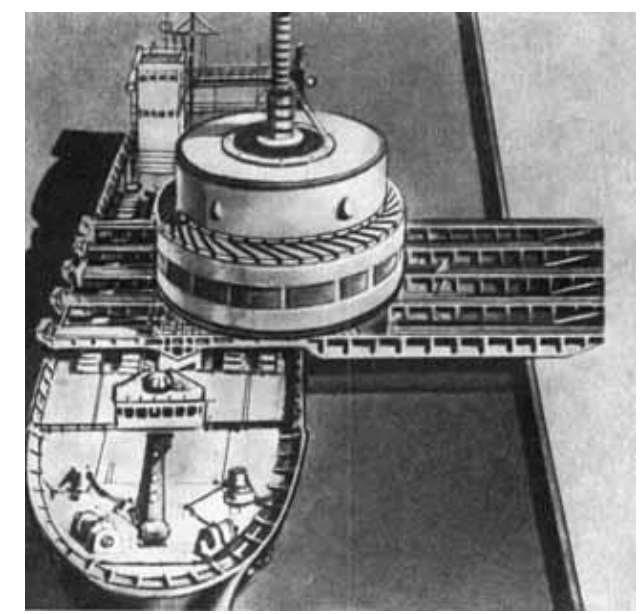

Рис. 2. Гідростатичні горизонтальні такелажні системи 
Аналіз останніх досягнень та публікацій, в яких розпочато розв`язування даної проблеми та висвітлювання нерозв язаних раніше частин загальної проблеми

Відома система змащування напрямних складається 3 групи карманів трикутної форми на поверхні напрямної, мастилопроводів та насосу 3 електроприводом (рис. 3) [4].

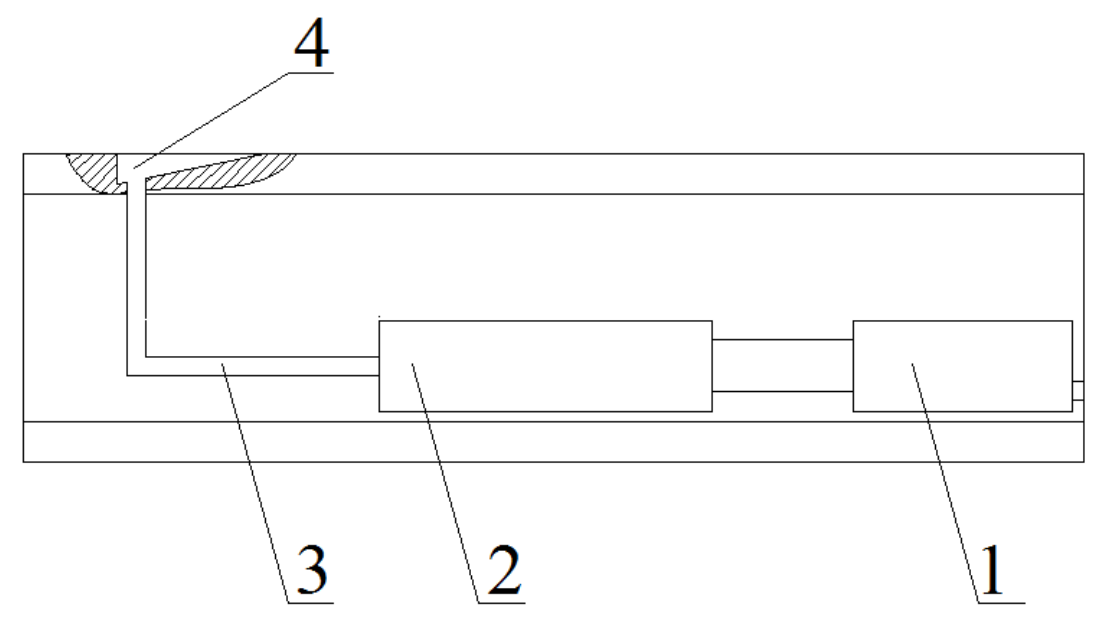

Рис. 3. Система змащування напрямних: 1 -електродвигун; 2 - насос; 3 -мастилопровід; 4 - змащувальний карман

Недоліки пристрою, які обумовлені застосуванням насосу 3 електроприводом та подачею мастила безпосередньо до карманів змащування:

- надлишкова витрата змащувального матеріалу;

- можливість підйому опорної поверхні вантажу над напрямною та створення перекидаючих моментів для вантажу;

- залежність низьков'язких сортів мастила, що застосовуються, від кліматичних умов;

- залежність роботоспроможності системи від наявності електричного живлення.

У меншій мірі експлуатаційні та конструктивні фактори впливають на характеристики систему змащування напрямних, яка складається 3 групи карманів трикутної форми на поверхні напрямної, мастилопроводів, дроселів та насосу з електроприводом ( рис. 4) $[4,5,6]$.

Недоліки пристрою, які обумовлені застосуванням комплексу «насос 3 електроприводом - дросель»:

- залежність низьков'язких сортів мастила, що застосовуються, від кліматичних умов;

- залежність роботоспроможності системи від наявності електричного живлення. 


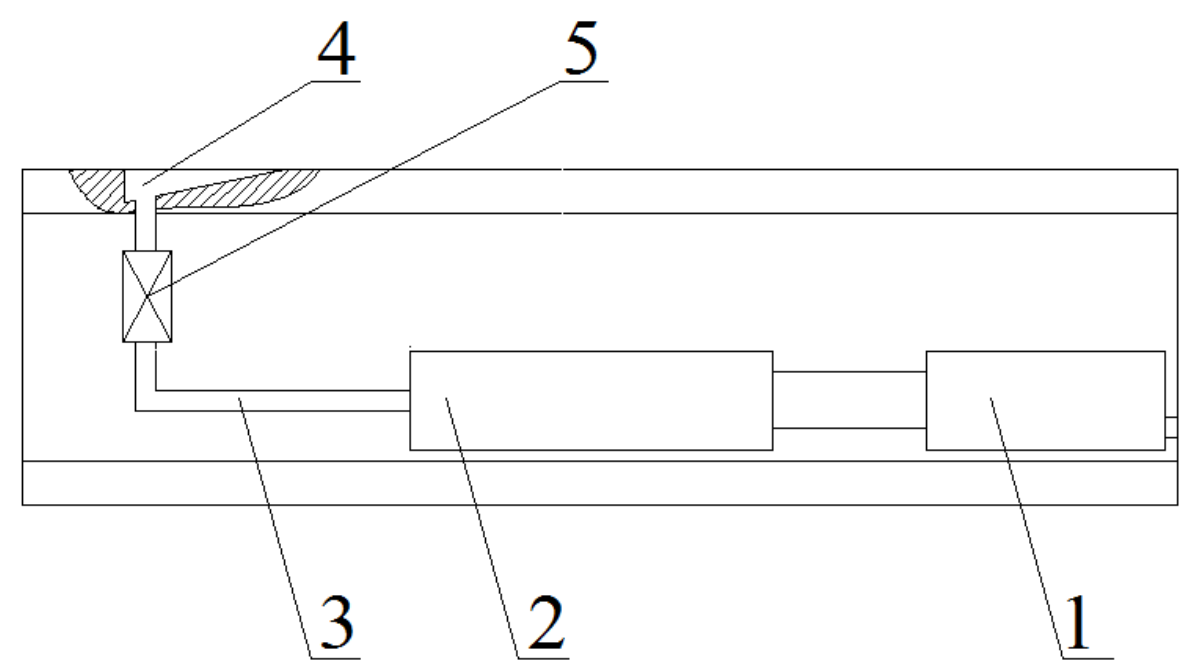

Рис.5. Система змашування напрямних: 1 - електродвигун; 2 - насос; 3 мастилопровід; 4 - змащувальний карман; 5 - дросель

\section{Формулювання мети статі (постановка задачі)}

В умовах, що склалися, доцільною стала розробка нового схемотехнічного рішення системи змащування напрямних. Передбачалося, що конструктивне виконання повинне забезпечити:

- можливість застосування консистентних мастильних матеріалів високої в'язкості з необхідною та достатньою витратою цих матеріалів;

- мінімізований вплив кліматичних чинників на вантажні операції;

- незалежність від електричного живлення;

- високий рівень забезпечення рідинного тертя у всьому діапазоні швидкостей та навантаження при пересуванні вантажу;

- простоту та надійність схемотехнічних рішень систем відомих типів.

Для розв язування поставленої задачі запропонована схема системи змащування напрямних.

\section{Виклад матеріалу дослідження з обгрунтуванням отриманих наукових результатів}

Суть запропонованого схемотехнічного рішення пояснюється кресленням (рис. 5), де зображена система змащування напрямних для переміщення надважких вантажів, що складається 3 напрямної 1 , карманів 2, дроселів 3 , мастилопроводів 4, ємності для мастильного картриджу 5, вторинного гідроциліндру 6 зі штоком-поршнем 8 , первинних гідроциліндрів 7, устрою перетворення поступального руху в обертальний 9 та зубчатої рейки 10 зі зворотною пружиною 11 .

Початок руху вантажу, що транспортується по направляючим, приводить до контакту опори вантажу та сферичної закінцівки зубчатої рейки. Під дією ваги вантажу зубчата рейка рухається у отворі напрямної до низу. При русі рейки вона приводить у дію устрій перетворення поступального руху в обертальний.

У свою чергу взаємодія поверхні барабану цього устрою з профільованою криволінійною канавкою з шістьома первинними гідроциліндрами призводить 
до підвищення тиску у гідравлічно зв'язаному 3 ними вторинному гідроциліндрі. Прі підвищенні тиску шток-поршень вторинного гідроциліндру витискує матеріал мастильного картриджу, у відповідній ємності, крізь дроселі до мастильних карманів. У такий спосіб мастило надходить у зону контакту вантажу та напрямної $[6,7]$.

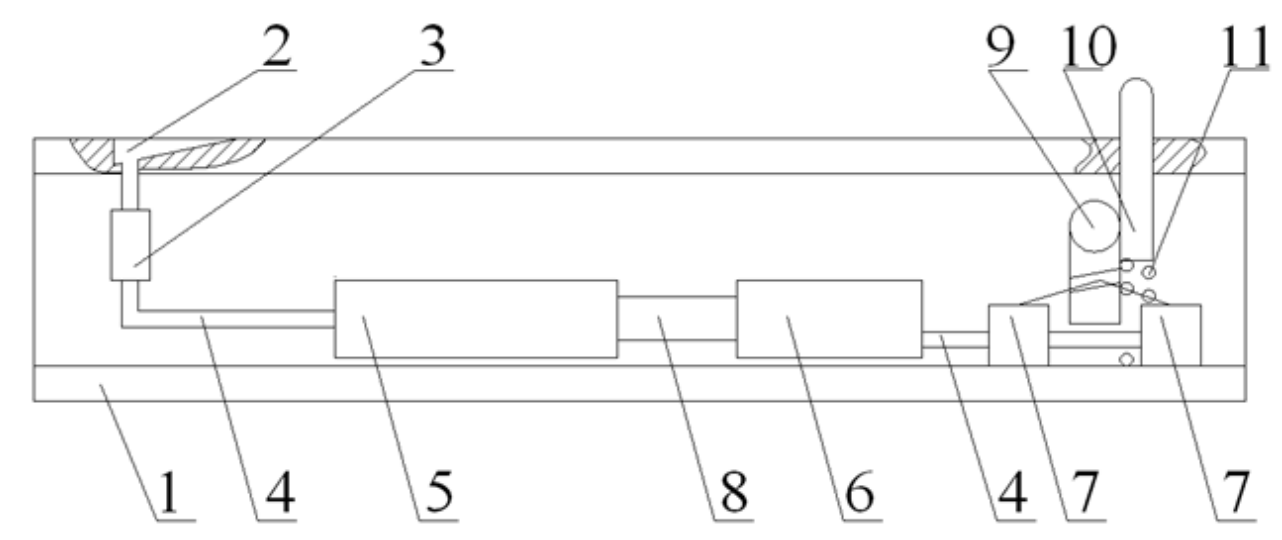

Рис.5. Система змащування напрямних для переміщення надважких вантажів: 1 напрямна; 2 -карман; 3 - дросель; 4 -мастилопровід; 5 - ємність для мастильного картриджу; 6-вторинний гідрочиліндр; 7 - первинний гідроииліндр; 8-иток-поршень вторинного гідроциліндру; 9 - устрій перетворення поступального руху в обертальний; 10 зубчата рейка; 11 - зворотна пружина

Для здійснення винаходу застосовано комбінацію гідромеханічних елементів.

У статичному режимі (перед початком вантажної операції) у ємність завантажується мастильний картридж та ємність замикається. Шток-поршень вторинного гідроциліндру знаходиться у вторинному гідроциліндру. Зубчата рейка піднята у верхнє положення зворотною пружиною.

У динамічному режимі (режим пересування вантажу) відбувається контакту опори вантажу та сферичної закінцівки зубчатої рейки. Під дією ваги вантажу зубчата рейка рухається у отворі напрямної до низу. При русі рейки вона приводить у дію устрій перетворення поступального руху в обертальний. У свою чергу взаємодія поверхні барабану цього устрою 3 профільованою криволінійною канавкою $з$ приводами 6 первинних гідроциліндрів призводить до підвищення тиску у гідравлічно зв’язаному 3 ними вторинному гідроциліндрі. Прі підвищенні тиску шток-поршень вторинного гідроциліндру витискує матеріал мастильного картриджу, у відповідній ємності, крізь дроселі до мастильних карманів. Дроселі, на яких відбувається зниження тиску, застосовуються для того, щоб при різному навантаженні на кармани, тиск в них не міг зрівнятися, а був максимальним тільки в зоні контакту. У такий спосіб мастило надходить до зони контакту вантажу та напрямної. Після проходження вантажу зони контакту з закінцівкою зубчатої рейки, вона під дією зворотної пружини піднімається догори, розвантажувальні клапани субсистеми «первинні гідроциліндри -вторинний гідроциліндр» відкриваються, тиск у вторинному гідроциліндрі знижується та поршень- шток повертається до гідроциліндру.

Таким чином, відбувається повний цикл системи змащування. 


\section{Висновки та перспектива подальшої роботи за даним напрямком}

Запропоноване схемотехнічне рішення відрізняється тим, що до складу системи залучені ємність для мастильного картриджу, силовий вторинний гідроциліндр, шток-поршень якого, під впливом тиску, що створюють шість первинних гідроциліндрів, що мають привід від устрою перетворення поступального руху в обертальний та зубчатої рейки, стискає мастильний картридж і забезпечує надання мастильного матеріалу у кармани змащування.

Таким чином у розробленій системі змащування комбінація гідромеханічних елементів забезпечує:

- створення більш адекватних умов змащування напрямних;

- можливість здійснення процесу змащування без залучення додаткових джерел живлення силового обладнання;

- врахування й компенсацію впливу гідрометеорологічних чинників, що впливають на вантажні операції;

- зниження витрат змащувального матеріалу.

Використання пристрою [8], що пропонується, дозволить здійснювати адекватний й економічний режим змащування при пересуванні вдовж напрямних надважких вантажів.

\section{ЛІТЕРАТУРА}

1. Подобед В.А., Подобед Р.В., Папуша А.Н., Вульфович Б.А. Транспортировка крупногабаритных особо тяжелых грузов морем // Вестник МГТУ. - 2014. - Том 17. - № 1. - С. 87 - 91.

2. Коробейников А. Ф. Исследование гидростатических направляющих // Вестник Хакасского технического института - филиала КГТУ. - Абакан, 2006. - № 22. - С. $42-47$.

3. Гаркунов Д.Н. Триботехника (конструирование, изготовление и эксплуатация машин). - М.: ГРНТИ, 2002. - 426 с.

4. Бушуев В.В. Гидростатическая смазка в станках. - М.: Машиностроение, 1989. - $176 \mathrm{c}$.

5. Hiwin. Линейные направляющие. http://www.linear.com.ua/catalog/hiwinlinear-motion.pdf.

6. Фещенко В.Н. Справочник конструктора. Книга 2. Проектирование машин и их деталей. - М.: Инфра-Инженерия, 2016. - 400 с.

7. А.c. 982867 СССР, М.Кл ${ }^{3}$ В 23 Q 1/02. Гидростатические направляющие металлорежущего станка/С.Н. Аграновский, Г.В. Гаврилова, Б.С. Шейнин; заявитель и патентообладатель: Особое конструкторское бюро станкостроения. - № 3297247/25-08; заявл. 05.06.81; опубл. 23.12.82. Бюл. № $47 .-2$ c.

8. Заявка на Деклараційний патент України на корисну модель № u201700572 від 20.01.2017. 